\title{
Torrefied Biomass and Where Is the Sector Currently Standing in Terms of Research, Technology Development, and Implementation
}

\author{
Michael Wild ${ }^{1,2}$ and Cristina Calderón ${ }^{2 *}$ \\ ${ }^{1}$ Wild \& Partner LLC, Vienna, Austria, ${ }^{2}$ International Biomass Torrefaction Council, Brussels, Belgium
}

Torrefaction is a thermal conversion method of biomass used to produce a high-quality solid biofuel that can be used for combustion, gasification, and additional non-energyrelated applications. Torrefied biomass has numerous advantages above today's standard biomass fuels like log wood, wood chips, and white wood pellets (WWPs). This is known and promoted for long, and has been proven in numerous research and demonstration projects; however, large-scale industrial proof is still underway only in these days. First,

OPEN ACCESS

Edited by:

Paola Brachi,

Istituto di Ricerche Sulla Combustione (IRC), Italy

Reviewed by: Temitope Olugbade, City University of Hong Kong, Hong Kong, SAR China José Airton De Mattos Carneiro-Junior, Bahia Federal Institute of Education, Science and Technology, Brazil

${ }^{*}$ Correspondence: Cristina Calderón calderon@bioenergyeurope.org

Specialty section: This article was submitted to Bioenergy and Biofuels, a section of the journal Frontiers in Energy Research

Received: 09 March 2021 Accepted: 10 May 2021 Published: 28 July 2021

Citation:

Wild M and Calderón C (2021) Torrefied Biomass and Where Is the Sector Currently Standing in Terms of Research, Technology Development, and Implementation.

Front. Energy Res. 9:678492. doi: 10.3389/fenrg.2021.678492 project implementations with name plate capacity of $100 \mathrm{kmt} / \mathrm{a}$ or higher are in construction or hot commissioning. In this review, the main advantages of torrefaction are shortly described, and the latest industry developments and future opportunities for the products as well as areas of need for further R\&D are presented.

Keywords: torrefaction, biomass upgrading, decarbonization, sustainability, market implementation, biocarbon, coal substitute

\section{INTRODUCTION}

Torrefaction is a process in which biomass, independent if it is woody or herbaceous biomass, biomass from agriculture, energy crops, land management, or even recycled biomass, is thermally treated, reducing the content of volatile components. Through the process, the biomass is changing a number of properties of the raw material towards the properties of very highly carbonized material and charcoal at substantial higher mass yield. Akin to pyrolysis and charring (full carbonization) in a general process setup, torrefaction is carried out at a lower temperature so that a higher proportion of the feedstock calorific value is retained in the resulting solid product still achieving the target to produce an ideal solid biofuel for many applications. The processes itself are very similar if not identical, and torrefaction installations can easily be used for full carbonization as well. It seems the association with temperature ranges to one, and the other process is rather vague. Hence, a differentiation between the three processes is resulting rather from the products and their use.

The thermal treatment not only destructs the fibrous structure and tenacity of biomass but is also known to concentrate the calorific value from feedstock into the final solid product. During the process of torrefaction, the biomass is heated to $180-350^{\circ} \mathrm{C}$ and partly devolatilizes, leading to a decrease in solid mass, but the initial energy content of the feedstock biomass is mainly preserved in the solid product. With a mass loss higher than energy content loss, the energy density of the torrefied biomass becomes higher than the original biomass, which makes it more attractive for transportation. If torrefaction gases are thermally oxidized and returned into the process in the form of heat for drying and torrefaction, the overall system efficiency is equal to white wood pellet 
production (Carbo et al., 2017). For handling, transport and storage torrefied biomass are densified into pellets or briquettes, best directly after torrefaction (Nanou et al., 2017). Those have improved water resistance which simplifies handling and storage of torrefied biomass above non-torrefied biomass (Stelte 2015). Torrefied biomass is superior to any nontreated biomass in the off-gassing behavior and is not subject to rotting, molding, or decomposition. Once densified, torrefied biomass shares many of the characteristics of coal (Järvinen and Agar 2014).

The torrefaction step represents an additional unit operation in the biomass processing chain. The attendant capital and operating costs, as well as conversion losses, are, however, offset by recirculating the heat from gas combustion and resulting in savings in drying as well as savings in other steps in the biomass utilization chain-logistics, storage, handling, milling, and combustion.

The authors, within the framework of their functions in the International Biomass Torrefaction Council IBTC, have carried out a survey in 2020 within the member companies of the IBTC followed by personal interviews on bilateral or multilateral basis. Survey and interviews had no scientific claims but rather the goal to get a feeling for the situation of the industry and the ongoing individual activities.

\section{UPCOMING OPPORTUNITIES FOR TORREFACTION}

The Paris agreement was the kickoff for the international commitment to mitigate climate change and reduce emissions. It was adopted by 196 Parties at COP21 in Paris, on December 12, 2015, and entered into force on November 4, 2016. Its goal is to limit global warming to well below 2, preferably to $1.5^{\circ} \mathrm{C}$, compared to preindustrial levels.

Following this spirit, the European Commission has set out along the road to achieving a climate neutral economy by 2050. Boosting the economy through green technology, establishing sustainable industry, and manufacturing whilst also reducing pollution are all central to the directive. Alongside the 2050 target, the Green Deal proposes reducing the EU Green House Gases (GHG) emissions by $50-55 \%$ by 2030 . Under the latest Member State climate plans, Europe was setting course for a $40 \%$ reduction. This is a considerable increase in ambition and will place a heavy reliance on the transformation of the power sector. The EU will need to push for huge growth in renewable power levels over the coming decades and an accelerated demise in coal, which offers a perfect opportunity for torrefied biomass as a sustainable alternative.

Bioenergy accounts for $56.6 \%$ of the EU total renewable energy consumption representing the largest renewable source in Europe and will remain so in the coming decades. This confirms that the sector is an indispensable and unavoidable companion of the European energy system.

In all scenarios worked out by the European Commission, there is a foreseen growth for bioenergy. EU bioenergy use is foreseen to increase by $49 \%$ by 2030 (according to the Member State plans and national energy and climate plans-NECPs) and by $59 \%$ in a long-term scenario, 2050 (according to the modeling of PRIMES-Price-Induced Market Equilibrium System). The biggest growth of bioenergy is expected to be seen in the industry sector, where torrefaction would offer a competitive alternative with more similar characteristics to the current fossil fuels being used. In addition, expectations for further increases in the EU emission trading system (ETS) carbon price is a key market mechanism to drive industrial interest in biomass resources (encompassing all heavy-industry subject to the EU ETS, including steel, cement, chemicals, and basic materials) and would drive more industrial consumers in the long term to consume torrefied biomass as it will decrease the competitiveness of the manufacturers who are more reliant on fossil-based products.

All the scenarios also foresee a higher share of electricity within the energy share, which will be between 35 and $65 \%$ of the final energy consumption in 2050-2 to 3 times higher than that today. Even if the tendency to electrification will mainly benefit other RES (renewable energy sources) such as wind and solar, biopower will increase to supply decarbonized electricity in a highly electrified final demand. In this sense, we may expect the replacement of coal by torrefied biomass in many power plants, as a way to ensure a transition to a clean energy, while local economy and jobs are maintained.

Besides, a key advantage of torrefied biomass is the reduced GHG emissions along the full supply chain compared to white wood pellets and even more so compared to wood chips, particularly in the case of long-distance transportation. In certain markets, this may become one of the main accelerators in the uptake of torrefied biomass, especially in view of the upcoming sustainability requirements in Europe.

Historically, the main consumers targeted by the torrefied biomass producers were the utilities for substitution of coal in their thermal power plants. Numerous trials had been carried out successfully in Europe and the United States (Nowling 2018). The downturn of thermal capacity as such and the existing project finance schemes for conversion projects (coal into biomass to coal co-firing or full conversion of coal to white wood pellets) were the key but not the only factors for slow uptake of torrefied products in this sector. However, to cope with the decarbonization objective and in view of an increasing price for carbon emission, future consumers of torrefaction products are also projected to be other industrial sectors such as the energy-intensive industries, but also from the heating sector, namely, district heating. Many producers of torrefied biomass work toward strategies that expand their markets beyond the power production (cofiring with coal or standalone) to the industrial use in sectors such as the mining and metallurgical industry, the nonmetallic mineral industry (glass, ceramic materials, and cement), or the chemical and petrochemical industries. Torrefied biomass is the most promising biomass fuel in those sectors even though the right form of application still needs to be found in some cases, and a variety of test programs is currently ongoing. 
The demand from those applications, in individual orders, may be smaller than that, for instance, in coal power plants regarding the volumes of product used. As such, the demand from these industries could support a more organic growth of the production facilities, which will also be much more to the taste of investors. Additionally, certain end-markets seeking a carbon dense feedstock do not have a conventional white pellet solution, and therefore, torrefied material will compete directly with fossil carbon. Torrefaction represents an easily grindable, renewable carbon alternative to fossil carbon for all markets and especially those markets that cannot work with raw biomass or white pellets. In certain industries and markets, the renewable carbon may even have a higher economical value than just the renewable calorific value. These, for the time being, niche markets show interesting revenue opportunities.

Those developments toward alternative markets have led a couple of torrefaction companies into higher degree of carbonization looking at future possibilities to expand into other related markets such as biochar (Airex, National Carbon, CEG, TorrCoal, etc.). Indeed, opening to other sectors will lead to the need of offering a broader array of products, that is, different degrees of torrefaction and different form factors.

During the torrefaction process, torrefaction gases are produced as by-product. The amount and calorific value as well as the chemical composition of this gas depend on the feedstock, but even more on the degree of torrefaction, that is, the degree of devolatilization of the feedstock. In a typical production of torrefied biomass for coal substitution, the torrefaction degree remains low, aiming to operate the process in the sweet spot of being self-sufficient in energy supply for drying and torrefaction. A higher degree of torrefaction will produce a higher calorific value solid product but also a surplus of torrefaction gas. Utilization of this gas is of paramount importance, not only economically but also in the LCA (life cycle assessment) of the torrefied biomass (AlanyaRosenbaum and Bergman, 2017). Today, it is mostly electricity that is generated from surplus gasses; however, extraction of some components of the torrefaction gasses will generate additional income for future installations (Prins et al., 2006, CEG 2019; Torrgas 2019) as does the combination of torrefaction with biomass gasification technologies as, for example, biomass chemical looping gasification. Not only are the gasification processes benefitting from the homogenous character of the torrefied biomass but also the processes benefit the $\mathrm{H}_{2} / \mathrm{CO}$ ratio of gas produced (Zhang et al., 2021).

Altogether, this development toward alternative markets could lead to significant improvement in the economic situation of individual companies and alleviate the market risk by broadening and enlarging the portfolio products and clients. The additional business opportunities, aside of coal substitution in power plant, in energy-intensive industries or with the commercialization of by-products for alternative markets, is already providing stimulus to the $s$ torrefaction sector. A variety of final consumers are increasing their use of biomass to meet the 2050 emissions targets, and torrefied biomass offers a perfect solution for a transition toward deep decarbonization.
Finally, beyond the climate commitment, we are living in a competitive world, and pricing is key to success. In this regard, bioenergy supply chain is more complex than other renewables, resulting in the creation of stable jobs and added value to many stakeholders in the forestry, agriculture, and energy sectors, but also in higher costs per GJ (energy unit) delivered to the final customer.

In this regard, bioenergy supply chain is different from other renewables. The supply chain is built by aligning a number of continuous processes-growing biomass, harvesting, processing, and transporting are the key chain elements, all of which demanding management, and generating stable jobs and added value to many stakeholders in the forestry, agriculture, transport, and industry sectors. This complexity results in costs higher than conventional carbon and sometimes also higher than other renewables; however, no other renewable energy is that easily storable, can be qualified as dispatchable, and can be consumed in the existing infrastructure.

The white wood pellet market is internationally growing by this proofing that the cost and price structures governing this market are viable. Hence, enforcing higher cost for clients is a luxury the torrefied biomass producer cannot afford. There will be certain premiums for the one or other characteristic of a dedicatedly produced torrefied product, but most actors in the sector do agree to submit to the benchmark character of the WWP pricing on GJ basis also for the torrefaction sector.

Not different to any other biomass fuel, producer competitiveness starts with reliable access to reasonably priced feedstock. A general fear is that in many regions of the world, wood prices might increase with increasing demand for wood for energy and to replace fossil fuel-based materials. Therefore, the availability of sustainable biomass is a decisive factor to determine the contribution of bioenergy to the future energy mix.

At present, most (about 70\%) of the biomass used for energy is woody-based biomass, mostly forest residues or residues from woodworking industries. However, recent studies reveal that agricultural biomass will play a central role in the future. To exploit the sustainable untapped potential by 2050, the energy contribution of agricultural biomass will need to increase significantly and become at least as important as that of energy from forest biomass. On the other hand, due to lower prices and higher availability, the interest in waste streams and residues as feedstock for energy is increasing.

A competitive edge of torrefied biomass is the feedstock flexibility. Each plant biomass can be torrefied. Torrefaction of various raw materials has extensively been studied in laboratory tests, and pilot- or demonstration-scale plants with all over very positive results regarding consumability of resulting fuel products (Tumuluru et al., 2011; Wilen et al., 2014). During thermal treatment, certain elements limiting the industrial use will be reduced, namely, $\mathrm{Cl}$ and $\mathrm{Hg}$. A recent study also suggests that the de-mineralization of biomass after thermal treatment is more effective than that prior to processing (Abelha and Kiel 2020). By this, many agricultural biomass sources become viable as basis for energy carriers, reducing the competition for woody biomass and eventually also reducing temporarily the feedstock cost for the processors. 


\section{CURRENT PRODUCTION}

The torrefaction industry, by now, probably with a dozen years of age, resembles in its development very well the white wood pellet industry in its first decade.

During the last two decades, many universities, research institutions, and private companies have investigated biomass torrefaction, aiming to learn more about the processes involved in torrefaction, the combustion characteristics, and getting a better understanding of the basic effect of the species, the particle size of raw material, temperature, heat transfer rates, residence time, and cooling necessities on the properties of the torrefied products. In addition, the densification process of the torrefied material, a necessity for storage and transport of torrefied biomass, had created its own challenges, which also had feedbacks to the process setup itself. Today, torrefied biomass is offered in the shape of pellets (by roller pressing or extrusion) or briquettes (by piston or roller briquetters or extruders) in line with ISO TS $17225-8$ requirements in mechanical durability $\mathrm{DU} \geq 97.5$ and fines content $\mathrm{F} \leq 2.0$. Depending on the degree of torrefaction, some biological additives in low percentages, like in the WWP, might be added to improve the durability and reduce energy consumption of densification. This forms factors for both: pellets and briquettes. Good results have also been achieved for briquetting mixes of lower and higher degree torrefaction biomass (Aamiri et al., 2019), mobilizing the lignin left in lower torrefied biomass as the binding agent.

The characteristics of the products are well described in ISO TS 17225-8, which after revision may soon be upgraded to a full standard: water sorption properties and grindability to form new parameters in the upgrade.

A number of companies have been immersed in a race to demonstrate technology leadership and supremacy. But the dropout rate has been much higher than the success rate, caused by overambitions, little experience in raw biomass handling in general, or the very slow pick up of products by the market, reminding very much the development in the first two decades of the WWP sector. At the end, a handful of companies have mastered the process both technically and economically, and are finally producing products that meet customer expectations in technical terms as well as in economic terms continuously and in meaningful quantities. Only Europe does see 3 industrial-scale plants with name plate capacity $100.000-160.000 \mathrm{mt} / \mathrm{a}$ in commissioning stage aside of a larger number of plants in the capacity range $7-25.000 \mathrm{mt} / \mathrm{a}$. In North America, a number of torrefaction and higher carbonization plants of $100.000 \mathrm{mt} / \mathrm{a}$ capacity are in the operation or commissioning stage partly also focusing on nonwoody biomass. A list of active projects as far as known to the authors is attached to this article. And it is likely that there will be several viable torrefaction technologies capturing the market over time as there seems not to be the one technology that is ideal for every purpose. Feedstock and requested product quality are the two poles to be connected, and in between, depending on the characteristics of the poles, one or the other technology offers advantages. Some of feedstock will cause better product results in the torrefaction process pre- or post-treated, mostly to reduce ash-forming mineral content chlorine and eventually sulfur.

Despite the fact that the advantages of torrefied biomass are promoted for years and have been proven in numerous research and demonstration projects, the project developers found themselves in a classical chicken or egg position. To finance a large-scale torrefaction plant, investors did require security of takeoff, but customers kept on seeing the "glass half empty rather than half full" and were requiring proof of continuous operation of an industrial-scale plant before required security would be granted by signing a purchase and supply contract. So, after completion of the demonstration plants, the sector found itself in a kind of stand by position, and it is only in these days that large-scale industrial proof is underway. Aside from the demonstration plants scattered around the globe, first, industrial-scale plants have started operation or are in the final stage of construction at the time this article was written. Terms of the supply contracts for products from these plants are not published, but it can be assumed that products contracted for energetic use will be valued on the net calorific value NDV basis and the prices will be based on the WWP I2 market prices on CIF or CPT basis. Price upmarks resulting from reduced costs in, for instance, but not limited to storage, milling, and hydraulic transport may be seen in individual applications.

Interestingly, the main customers are not only in the traditional group of European power plant operators who have, in many cases, completed investment in conversion hardware for white wood pellet consumption but also in regions and sectors that were not the first movers.

\section{RESEARCH}

With time and a continuous research, many questions and challenges around the torrefaction of biomass and all the thermodynamic reactions involved has been solved and overcome. Nevertheless, there is still the need of further research related to the adequate adaptation of the process' parameters to the different types of feedstock, mastering the densification process, defining the best use of surplus torrefaction gas streams, and understanding the potential industrial application opportunities of torrefied biomass.

The ever-increasing need to decarbonize industrial production processes results in a higher demand for biomass-based solid fuels. The characteristic of natural biomasses prevents their use in these processes, which is why the only option left is to substitute the previously used energy sources with torrefied or highly carbonized biomass. This results in a number of questions that have not yet been adequately answered. The integration of biocarbon from biomass torrefaction processes into industrial production processes appears to be much more complex than simple co-combustion in power plants. The qualities and properties of the final product of the industries are in the center, and the production factors have to be oriented to this. Both this integration to optimize and the resulting requirements for the intermediate product torrefied biomass form in each 
TABLE 1 | Torrefaction facilities.

\begin{tabular}{|c|c|c|c|c|c|}
\hline Location & Status & Commissioning & $\begin{array}{c}\text { Name plate } \\
\text { capacity }\end{array}$ & Intended NCV & $\begin{array}{l}\text { Product form } \\
\text { factor }\end{array}$ \\
\hline Austria & Project in operation & Since 2013 & 8.000 tonnes/year & $22-23 \mathrm{MJ} / \mathrm{kg}$ & Briquette $70 \mathrm{~mm}$ diameter \\
\hline Belgium & Project in operation & $\begin{array}{l}\text { Pelletizing on industrial scale } \\
\text { expected in } 2022\end{array}$ & $\begin{array}{l}\text { Powder } 30.000 \\
\text { tons/year } \\
\text { Pellets } 150 \mathrm{~kg} / \text { hour }\end{array}$ & $\begin{array}{l}\text { Powder } 22-28 \mathrm{MJ} / \mathrm{kg} \\
\text { pellets } 21 \mathrm{MJ} / \mathrm{kg}\end{array}$ & $\begin{array}{l}\text { Powder (full production) } \\
\text { Pellets (only for test } \\
\text { purposes) }\end{array}$ \\
\hline Croatia & Project in permitting phase & 2020 & $\begin{array}{l}4.500 \text { tonnes/year } \\
1.000 \mathrm{~kW} \text { electricity }\end{array}$ & $\mathrm{C}_{\mathrm{fix}} 90-98 \%$ & Charcoal $150 \mathrm{~mm}$ \\
\hline Estonia & Project under construction & Q4 2020 & $\begin{array}{l}157.000 \text { tonnes/ } \\
\text { year }\end{array}$ & $21 \mathrm{MJ} / \mathrm{kg}$ & Pellet \\
\hline Finland & Project in final negotiation & 2023 & 60.000 tonnes/year & 22-23 MJ/kg & Briquette $70 \mathrm{~mm}$ diameter \\
\hline Germany & Project in operation & Since 2016 & 3.000 tonnes/year & $\mathrm{C}_{\mathrm{fix}} 90-98 \%$ & Charcoal 150 mm \\
\hline Ireland & Project in operation & & 10.500 tonnes/year & n.a & n.a \\
\hline Portugal & $\begin{array}{l}\text { Project in operation (not yet } \\
\text { at full capacity) }\end{array}$ & Q4 2020 & $\begin{array}{l}120.000 \text { tonnes } \\
\text { black pellets } \\
80.000 \text { tonnes white } \\
\text { pellets }\end{array}$ & $18-22 \mathrm{MJ} / \mathrm{kg}$ & Pellet \\
\hline Portugal & Project under construction & 2020 & 100.000 tonnes & $22 \mathrm{MJ} / \mathrm{kg}$ & $\begin{array}{l}\text { Woodchips } \\
\text { Pellet }\end{array}$ \\
\hline United Kingdom & Project in operation & & 30.000 tonnes/year & $21 \mathrm{MJ} / \mathrm{kg}$ & Pellet \\
\hline Russia & Project in permitting phase & Q4 2021 & $\begin{array}{l}2 \times 40.000 \text { metric } \\
\text { tonnes/year }\end{array}$ & $21-25 \mathrm{MJ} / \mathrm{kg}$ & Pellet \\
\hline Canada (BC) & Project in permitting phase & Q1 2021 & 100.000 tonnes & $21 \mathrm{MJ} / \mathrm{kg}$ & Pellet \\
\hline Canada (QC) & Project in operation & 2016 & 15.000 tonnes & $21 \mathrm{MJ} / \mathrm{kg}$ & Pellet \\
\hline United States & Project in operation & 2012 & 75.000 tonnes/year & 25-30 MJ/kg & Pellet \\
\hline United States & Project in permitting phase & 2022 & $\begin{array}{l}400.000 \text { tonnes/ } \\
\text { year }\end{array}$ & $25-30 \mathrm{MJ} / \mathrm{kg}$ & Pellet \\
\hline $\begin{array}{l}\text { United States } \\
\text { (Louisiana) }\end{array}$ & Project in operation & 2017 & 16.000 tonnes/year & $19 \mathrm{MJ} / \mathrm{kg}$ & Pellet, briquette \\
\hline $\begin{array}{l}\text { United States } \\
\text { (Oregon) }\end{array}$ & Project in operation & 2019 & 90.000 tonnes/year & $21-22,5 \mathrm{MJ} / \mathrm{kg}$ & Pellet, briquette \\
\hline United States & Project under construction & Q3 2021 & $\begin{array}{l}125.000 \text { tonnes/ } \\
\text { year }\end{array}$ & $30 \mathrm{MJ} / \mathrm{kg}$ & Pellet, briquette \\
\hline $\begin{array}{l}\text { United States } \\
\text { (Oregon) }\end{array}$ & Project under construction & n.a & $\begin{array}{l}100.000 \text { tonnes/ } \\
\text { year }\end{array}$ & n.a & $\begin{array}{l}\text { Softwood TorrB }{ }^{\circledR} \text { torrefied } \\
\text { biomass briquette }\end{array}$ \\
\hline Indonesia & Project in final negotiation & Q1 2021 & 80.000 tonnes & $21 \mathrm{MJ} / \mathrm{kg}$ & Pellet, briquette \\
\hline Thailand & Project in developments & Q3 2020 & 15.000 tonnes & $20 \mathrm{MJ} / \mathrm{kg}$ & Pellet \\
\hline Ethiopia & Project in final negotiation & 2023 & 60.000 tonnes/year & $22-23 \mathrm{MJ} / \mathrm{kg}$ & Briquette $70 \mathrm{~mm}$ diameter \\
\hline
\end{tabular}

industry sector for itself still a large number of unknowns and a wide playground for research and development. Projects like the TORERO (www.torero.eu) are the tip of an "iceberg"-like demand in further findings and solutions.

Also, all the possibilities for torrefied biomass from the replacement of pet-coke-derived carbon black in a wide variety of products and sectors seemed far from being sufficiently explored and offered a wide range of possibilities with high implementation potential for both researchers and process developers.

\section{FINAL CONSIDERATIONS}

While white wood pellets are getting better and better established as a renewable commodity torrefied biomass despite its technical, economical, and GHG advantages, it still has to fight the chicken and egg problem of no investment finance of processing plants if no long-term off- take security is provided which in turn seems to only be available if proof of process in industrial-scale facilities is produced.

A couple of producing companies have taken the risk and have established industrial-scale plants (see Futerra, CEG, National Carbon, Polytechnik, and AFS), accelerating the speed of market deployment of torrefied biomasses, and the number of projects in the pipeline is very encouraging, leading to sectorial and geographical broadening and increasing interest in the torrefied product. For producers of torrefied biomass, the customer focus is shifting from a pure focus on thermal power plants to a wide variety of industries as one of the very few opportunities to replace fossil carbon with renewable biocarbon in the production processes but also in the products themselves. Trials are at an advanced stage in many places, yet a wide field of further development and research remains.

Torrefied biomass in briquette or pellet shape is one of the readily available and economically affordable solutions to 
phase out fossil fuels not only in the power sector but also in a variety of industrial processes with a large number of unique selling points in the sector of biogenic resources which has already led to acceleration in the implementation of torrefaction systems and whose further, certainly exponential growth seems unstoppable from today's perspective .

\section{AUTHOR CONTRIBUTIONS}

All authors listed have made a substantial, direct, and intellectual contribution to the work and approved it for publication.

\section{REFERENCES}

Aamiri, O. B., Thilakaratne, R., Tumuluru, J. S., and Satyavolu, J. (2019). An "InSitu Binding" Approach to Produce Torrefied Biomass Briquettes. Bioengineering (Basel) 6, 87. doi:10.3390/bioengineering6040087

Abelha, P., and Kiel, J. (2020). Techno-economic Assessment of Biomass Upgrading by Washing and Torrefaction. Biomass and Bioenergy 142, 105751. doi:10.1016/j.biombioe.2020.105751

Alanya-Rosenbaum, S., and Bergman, R. (2017). Life-cycle Analysis of Torrefying post-harvest wood Residues. Waste to Wisdom Webinar Aug $9^{\text {th }} 2017$.

Carbo, M., et al. (2015). "Presentation from Final Meeting of SECTOR Project - the Production of Solid Sustainable Energy Carriers from Biomass by Means of Torrefaction. Session II - Logistics," in Presented at Final Project Meeting, Petten, Leipzig, 6-7 May 2015.

Carbo, M., Nanou, P., Nordin, A., Gil Barno, J., and Goni Zubillarga, I. (2017). MぬE Balances for Pellet Production of wood vs. Torrefied wood. ECN Poster 4_2017PN.

IEA (International Energy Agency) (2021). Decarbonizing Industrial Process Heat: The Role of Biomass.

Järvinen, T., and Agar, D. (2014). Experimentally Determined Storage and Handling Properties of Fuel Pellets Made from Torrefied Whole-Tree pine Chips, Logging Residues and Beech Stem wood. Fuel 129, 330-339. doi:10.1016/j.fuel.2014.03.057

Nanou, P., Huijgen, W. J. J., Carbo, M. C., and Kiel, J. H. A. (2017). The Role of Lignin in the Densification of Torrefied wood in Relation to the Final Product Properties. Biomass and Bioenergy. doi:10.1016/ j.biombioe.2017.05.005

Nowling, U. (2018). Successful Torrefied Biomass Test at a Coal Power Plant. onlinepublication Available at: www.powermag.com Accessed March 1, 2018, p46-52.

Olsson, O., Lamers, P., Schipfer, F., and Wild, M. (2016, Commoditization of Biomass Markets, 139, 163. doi:10.1016/B978-0-12-805165-8.00007-0

Prins, M. J., Ptasinski, K. J., and Janssen, F. J. J. G. (2006). More Efficient Biomass Gasification via Torrefaction. Energy 31 (15), 3458-3470. doi:10.1016/ j.energy.2006.03.008

Stelte, W. (2015). Best Practice Guideline - Storage and Handling of Torrefied Biomass. Danish Technology Institute.

Suopajärvi, H., Umeki, K., Mousa, E., Hedayati, A., Romar, H., Kemppainen, A., et al. (2018). Use of Biomass in Integrated Steelmaking - Status Quo, Future Needs and Comparison to Other low-CO2 Steel Production Technologies. Appl. Energ. 213, 384-407. doi:10.1016/j.apenergy.2018.01.060

\section{ACKNOWLEDGMENTS}

For the purpose of this article, the authors conducted interviews with experts on the torrefaction market. The following experts, members of the International Biomass Torrefaction Council (IBTC), offered advice on the torrefaction technology and market prospects: W. Sitzmann, Y. Ryckmans, and J. Mennell in 2019, and J. Sluijsmans, R. Johnson, S. Bertrand, A. Johnson, S. Paskett, B. De Vries, V. Radić, W. Moser, J. Spaan, D. Derksen, and I. Santos in 2020. The authors would like to thank these members of the IBTC for providing the data displayed in Table 1 and for their useful discussions. For more information, the reader is invited to visit https://ibtc.bioenergyeurope.org/.

Thrän, D., Witt, J., Schaubach, K., Kiel, J., Carbo, M., Maier, J., et al. (2016). Moving torrefaction towards market introduction e Technical improvements and economic-environmental assessment along the overall torrefaction supply chain through the SECTOR project. Biomass and Bioenergy 89, 184-200. doi:10.1016/j.biombioe.2016.03.004

Tumuluru, S., J., Sokhansanj, S., Hess, J. R., Wright, C. T., and Boardman, R. D. (2011). REVIEW: A Review on Biomass Torrefaction Process and Product Properties for En-Ergy Applications. Ind. Biotechnol. 7 (5), 384-401. doi:10.1089/ind.2011.7.384

Wild, M., Deutmeyer, M., Bradley, D., Hektor, B., Hess, J. R., Nikolaisen, L., et al (2016). Possible Ef-Fects of Torrefaction on Biomass Trade. IEA Bioenergy.

Wilén, C., Jukola, P., Järvinen, T., Sipilä, K., Verhoeff, F., and Kiel, J. (2013). Wood Torrefaction - Pilot Tests and Utilisation Prospects. Espoo: VTT Technology, $122,73$.

Wilén, C., Sipilä, K., Tuomi, S., Hiltunen, I., Lindfors, C., Sipilä, E., et al. (2014). Wood Torrefaction - Market Prospects and Integration with the forest and Energy Industry. Espoo: VTT Technology, 163, 55.

Zhang, R., Zhang, J., Weo, G., Wu, Z., Wang, Z., and Yang, B. (2021). Effect of Torrefaction Pretreatment on Biomass Chemical Looping Gasification (BCLG) Characteristics: Gaseous Products Distribution and Kinetic Analysis. Energ. Convers. Manage. 237, 114100. doi:10.1016/j.enconman.2021.114100

Conflict of Interest: The author MW is owner of Wild \& Partner LLC and the honorary President of the International Biomass Torrefaction Council. The author $\mathrm{CC}$ is employed by Bioenergy Europe and is Secretary General of the International Biomass Torrefaction Council.

Publisher's Note: All claims expressed in this article are solely those of the authors and do not necessarily represent those of their affiliated organizations, or those of the publisher, the editors and the reviewers. Any product that may be evaluated in this article, or claim that may be made by its manufacturer, is not guaranteed or endorsed by the publisher.

Copyright (c) 2021 Wild and Calderón. This is an open-access article distributed under the terms of the Creative Commons Attribution License (CC BY). The use, distribution or reproduction in other forums is permitted, provided the original author(s) and the copyright owner(s) are credited and that the original publication in this journal is cited, in accordance with accepted academic practice. No use, distribution or reproduction is permitted which does not comply with these terms. 